\title{
Perspectives of the services provided by the human resource function
}

\author{
Jay Owens \& Joan van der Merwe \\ Graduate School of Business Administration, University of the Witwatersrand, 1 Jan Smuts Avenue, P.0. Wits 2000 \\ Republic of South Africa
}

Received February 1992, accepted April 1993

\begin{abstract}
The aim of the research was to study organizational perceptions of the quality of service rendered by human resource directors. In this article we focus on the service of equipping first-line managers for their human resource function. Key abilities and skills required by first-line managers were identified in the literature and verified in eight interviews. These were included in the questionnaire to focus the thinking of respondents. Forty questionnaires were received from a stratified sample of directors and managers of ten organizations. Respondents were requested to rate the service quality attributes as defined by Parasuraman, Zeithaml \& Berry in terms of the service provided by the human resource function. Rated service quality determinants were modelled on Thurstone's Case $V$ Scale Model, yielding a unidimensional interval scale from comparative judgements. Measurement of the perceived service quality was a starting point in defining deficiencies in the service orientation of the human resource function.

Die doel van hierdie navorsing was om die organisatoriese persepsies van die diensgehalte wat deur die direkteure van menslike hulpbronne verskaf word. te bestudeer. In die artikel word gefokus op die diens wat daaruit bestaan om die eerstelynbestuurders met die nodige vaardighede vir hul menslike hulpbronfunksie toe te rus. Sleutelkundighede en -vaardighede wat deur eerstelynbestuurders benodig word, is in die literatuur geïdentifiseer en deur middel van agt onderhoude bevestig. Hierdie vaardighede is in die vraelys ingesluit ten einde die denke van die respondente te help fokus. Veertig vraelyste is van 'n gestratifiseerde steekproef van direkteure en bestuurders in tien organisasies ontvang. Respondente is versoek om die eienskappe van diensgehalte, soos deur Parasuraman, Zeithaml \& Berry gedefinieer ten opsigte van die diens wat deur die menslike hulpbronfunksie gelewer word, te evalueer. Die geëvalueerde eienskappe van die diensgehalte gelewer, is op die Thurstone Case V-skaal gemodelleer wat 'n eendimensionele afstandskaal van vergelykende oordele opgelewer het. Die bepaling van die persepsies van diensgehalte het as vertrekpunt gedien om leemtes in die diensgerigtheid van die menslike hulpbronfunksie te omskryf.
\end{abstract}

\section{Introduction and problem definition}

The fundamental, yet often neglected, resource of any organization is its people. Cascio (1986) maintains that the human resource function of an organization should be owned by line management. The real job of the human resource director is to make human resource skills available to line management and the incumbent should focus on developing a human resource consciousness within the company and work at developing the actual skills, abilities and talents of the people inside the organization, while personnel administration should be delegated to suitably qualified personnel officers. Effective performance would require that the human resource director market his services within the organization. In the marketing of services, service quality is enmeshed with the service deliverer (Kotler, 1988). Both the outcome of the service and the process of service delivery impact on the evaluation of its quality.

Parasuraman, Zeithaml \& Berry (1985) maintain that consumers use ten determinants of service quality in forming expectations about, and perceptions of, any type of service. Consumers' perceptions of service quality are likely to be affected by four distinct gaps on the service providers' side, one of which is believed to exist between consumer expectations and management perceptions of consumer expectations. Perceptual differences play a role in the need identification process.

In this research, the human resource function is equated with the service deliverer or provider and management with the consumers or customers of the service. In particular, the service of equipping front-line managers for their human resource function, came under scrutiny. Since an organization's human resource is of strategic importance, the ability of line managers to effectively exercise their human relations skills impacts positively on return on investment, profits and productivity (Garvin, 1983).

Rabin (1983) maintains that the search for quality was the most important consumer trend of the 1990s. Consumers are now demanding higher quality in products and services than ever before (Leonard \& Sasser, 1982; Takeuchi \& Quelch, 1983). In the South African context, the problem is that first-line managers are not always skilled to handle the peculiar problems facing them in a changing South Africa. Supervisors need to acquire, develop and reinforce their technical, administrative and people skills.

Measuring the quality of the human resource practitioners' service to the front-line management is a starting point in defining service deficiencies. Once quality has been assessed, the correct process in terms of training, educating and motivating human resource practitioners meaningfully, can be refined to meet the particular challenges in a developing South Africa.

The purpose of this research was to identify the differences in perceptions between human resource directors and line managers in terms of the service they provide to firstline managers in equipping them for their human resource role.

\section{Review of related literature}

\section{Human resource role of front-line managers}

Conventional philosophy dictates that the prime responsibility for managing people, including the effective management of physical and financial resources, rests with line management (Barrington, 1978). This suggests that the most effective approach to human resource management may result from close interaction, or joint responsibility, between 
the personnel department, which is charged with the administration of human resource management, and line managers, who are charged with the responsibility of optimizing all their resources (Cascio, 1986).

Various authors have deliberated on the skills required by supervisors in carrying out this responsibility. Warrick \& Zawacki (1984) maintain that the actual skills used by supervisors and managers are the same, the differences being in skills emphasis and application methods. Supervisors, usually more concerned with the daily scheduling of work, require skills in leading, staffing, planning and setting objectives, organizing and controlling, communicating, counselling and evaluating performance. This view is supported by Kirkpatrick (1990) who believes that an effective supervisory training and development programme should address the topics of leadership, motivation, communication, decision-making, problem-solving, time management and subordinate training. In a similar way, the topics identified, concern the daily scheduling of work.

In contrast with the skills identified by Warrick \& Zawacki (1984), and Kirkpatrick (1990), the American Marketing Association's Multimedia Supervisory Management Course (McConnell, 1971) addresses twelve essential management skills, while an international labour organization study into supervisory skills, produced 35 basic subject areas, fourteen of which appeared $95 \%$ of the time.

Since a standard or universal mix of managerial, technical and operative functions in the supervisory role could not be defined, it was felt that this should be defined in individual situations, since the mix of functions may differ substantially within the same industry, company or department (Prokopenko \& Bittel, 1981).

A review of the anticipated future directions of the supervisory role leads to the general conclusion that supervisors believe their job will require the existence of an individual who is more of a leader and a teacher/coach than the traditional industrial policeman (Peters, 1987; Bennis \& Nanus, 1985). This change will require that the first-level supervisor excels in interpersonal and other human resource skills.

In adjusting the focus to meet the demands of the future, it is important to understand that today's supervisor is managing in a turbulent environment; that he is the key link between middle management and the operating worker, and plays a major role in the success of organizations; that supervision is a professional skill that most people can learn through proper training; and that the supervisor must have technical, human and conceptual skills, the last of which is deemed to be the most important (Warrick \& Zawacki, 1984; Lewis, 1974).

\section{Perceptions of service quality - three themes}

Zeithaml et al. (1988) maintain that the delivery of quality in goods and services has become a marketing priority. Marketers of tangible goods have defined and measured quality with increasing levels of precision (Crosby, 1979; Garvin, 1983). Consumer expectations of goods do not offer many problems because consumers can use their senses or imagine product qualities (Lovelock, 1984). However, marketers of services experience difficulties in understanding and controlling quality. Quality is defined as 'excellence' (Chambers Twentieth Century Dictionary, 1974), and is a relative concept, as perceived by the consumer, and dependent on the customer's previous experience, attitudes, motivation and needs (Jacobs, 1988).

A number of authors, including Shostack (1977) and Berry (1980), argue that thene are significant distinctions between goods and services, and propose several broad generalizations for management practice. Yet others, such as Enis \& Roering (1981), remain unconvinced that these differences have meaningful implications. Lovelock (1984) contends that many of the marketing techniques developed in manufacturing organizations cannot be transferred to those in services because their intrinsic characteristics differ from those of goods.

In most services, quality occurs during the service delivery, usually in an interaction between the customer and contact personnel of the service firm. Thus service quality is highly dependent on the performance of employees, an organizational resource that cannot be controlled to the degree that components of tangible goods can be engineered. Parasuraman et al. (1985) identify three underlying themes in the literature regarding service quality, namely, that service quality is more difficult for the consumer to evaluate than goods quality; that service quality perceptions result from a comparison of consumer expectations with actual performance; and that quality evaluations are not made solely on the outcome of a service, but also involve evaluations of the process of service delivery.

In support of the first theme, Rathmell (1966) proposes that most market offerings might best be described along a continuum from pure goods to pure services. Differences in consumer evaluation processes between goods and services can be isolated in the classifications of qualities of goods, i.e. search, experience and credence qualities. In support of this, Zeithaml (1981) proposes eleven hypotheses about the differences between service and product evaluation processes. Fisk (1981) maintains that consumer evaluations of services will be more personalized and dynamic, and require more cognitive evolvement than evaluations of goods as a result of the high degree of intangibility.

In support of the second theme, service quality is stated to be a measure of how well the service level delivered matches the customer expectations. Delivering quality service means conforming to customer expectations on a consistent basis, thus managing service quality involves managing customer expectations as well as the service assembly process (Lewis \& Booms, 1983).

Sasser, Olsen \& Wyckoff (1978) identify the critical role of the service level of firms. Expected service levels are met by delivering those components of the service that are perceived by the customer to be important, such as intangibles like atmosphere, consistent quality, pleasant interpersonal relations.

Customers may experience difficulty in imagining the desired service until after experiencing it. Dissatisfaction with service may be easily perceived by the customer, yet 
imagining proposed solutions may be even more problematic (Beckwith \& Fitzgerald, 1981). Zeithaml (1981) hypothesizes that consumers attribute some of their dissatisfaction with services to their own inability to specify or perform their part of the service, while in Gronroos' (1984) model, consumers are stated to evaluate service quality by comparing expected service with perceptions of the service they receive.

Smith \& Housten (1983) claim that satisfaction evaluations of services are related to confirmation or disconfirmation of expectations. The evaluation process is based on a cognitive script, a mental representation of knowledge about events. This service-evaluation process is also consistent with Churchill \& Suprenant's (1982) disconfirmation paradigm.

The third theme is supported by the following: in both goods and service organizations, various inputs are converted into need satisfying products through a series of steps - production, purchase, use and evaluation. In the goodsproduction and consumption process, the steps can be separated in time and space, while in service production the steps are essentially simultaneous, resulting in an intensive and complex interface between customer and firm throughout the process (Booms \& Bitner, 1981). Lovelock (1984) proposes that the service operation can be considered as comprising three overlapping systems, namely, the operations system, the delivery system and the marketing system. Parts of the service-operation system are visible to the customers, others are hidden from view and the customer may not even know of their existence. The visible components can be divided into those relating to physical facilities and contact personnel. Customers may find themselves interacting with either or both of these and also, possibly, with other customers (Lovelock, 1984; Shostack, 1977).

Fisk (1981) maintains that evaluative processes occur continuously in consumer behaviour, becoming conscious only at certain stages of this behaviour. In his model, each of the three behaviours, namely, alternative selection, choice and use, serve as a 'triggering cue', (Day, 1977) for evaluative purposes. Consumer evaluation during the consumption, or post choice evaluation of services, is thus a significant aspect of services (Fisk, 1981; Hawkins, Coney \& Best, 1980; Ortinau, 1979).

Lehtinen \& Lehtinen (1982) believe that service quality is produced in the interaction between a customer and elements in the service organization. Their three quality dimensions are: physical quality, corporate quality and interactive quality. They also distinguish between the processes of service delivery and the quality associated with the outcome of the service. Sasser et al. (1978) list three dimensions of service performance and imply that service quality involves more than outcome. Berry (1980) underscores this when he points out that the presence of the service provider makes the 'how' of service distribution important.

Services are therefore experiential, with service elements offering clues about the nature and quality of the service product. It is thus the responsibility of the human resource department to communicate clearly to management what it can offer and what in retum can be expected from the department (Cascio, 1986).
Parasuraman et al. (1985) develop a model of service quality which suggests that quality perceptions of consumers are influenced by a series of four distinct gaps occurring in organizations, namely Gap 1 - the difference between consumer expectations and management perceptions of consumer expectations; Gap 2 - the difference between management perceptions of consumer expectations and service quality specifications; Gap 3 - the difference between service quality specifications and service quality actually delivered; and Gap 4 - the difference between service delivery and what is communicated about the service to consumers. Perceived service quality, Gap 5, is the difference between consumer expectations and the perceptions of the service quality, and depends on the size and direction of the other four gaps. These researchers postulated that consumers use ten criteria in determining service quality, regardless of the type of service. This model provides a sound conceptual foundation for investigating service quality. In this research it is applied to the human resource function which faces the challenge of delivering a consistently good service to the organization. The responsibility for the service product design of the human resource function (Gap 2), service delivery (Gap 3) and marketing (Gap 4) is that of the human resource director. The way the service is perceived by the customer, in this case the employees (Gap 5), depends on the design, marketing and delivery of the service.

The difference between consumer expectations and director perceptions of those expectations, impacts on the effectiveness of the human resource function. Service firm executives may not always understand what features connote high quality service to consumers in advance; what features a service must have in order to meet consumer needs; and what levels of performance on those features are needed to deliver high quality service (Parasuraman et al., 1985). The larger the gap, the less likely that customer expectations will be met. An understanding of Gap 1 was thus the focus of this research, which addressed three questions, namely, what determinants of quality are considered of importance by the service provider, i.e. the human resource function; what determinants of quality are considered important by the consumers of the service; and what is the difference in perceptions of these groups.

With the research we therefore attempted to obtain ratings of key attributes of a quality human resource function service by managing directors, human resource directors, functional directors and first-line managers, and attempted to determine what discrepancies exist between the perceptions of human resource directors and those of managing directors, functional directors, and first-line managers by means of Thurstone's Case V Model (Green \& Tull, 1978). It was hypothesized that there is a significant difference between the ratings of service quality determinants by service providers and service consumers.

\section{Research methodology}

\section{Sample selection}

The 1989 membership directory of the Witwatersrand Chamber of Commerce and Industry was used to generate a list of companies in Johannesburg employing more than two thousand workers. It was judged that an organization of this 
size could justify a human resource function headed by a human resource director. Forty such organizations were identified. A random number table was used to select ten companies for research purposes by replacement sampling.

Permission to conduct research in the company was obtained from the managing director of the companies identified, and the human resources director of each participating company contacted to explain the aim of the study and to arrange for delivery and return of the questionnaire. The names of the functional director and of a first-line manager reporting to the latter were obtained. Systematic sampling was used to select a functional area in each participating organization, which ensured even distribution of functional areas across the sample, namely operations, marketing, administration, finance and information systems. The named functional directors and first-line managers were contacted, the aim of the study explained and arrangement was made for delivery and return of questionnaires.

\section{Questionnaire design}

A questionnaire was designed to address the research question raised. It was kept as short and simple as was meaningfully possible to encourage participation, to restrict costs, and to facilitate analysis and interpretation. The first six questions pertained to such demographic details as name, company, management position, number of years in the position and number of years in the company and age category.

The seventh question pertained to the human relations skills of the first-line managers. A list of these skills had been compiled from the literature survey and verified in eight in-depth interviews conducted with managing directors, human resource directors, functional directors and firstline managers from two organizations which had been randomly selected from the remainder of the population. Respondents were simply asked to mark relevant skills in response to question seven. The purpose of this question was to provide the respondents with a frame of reference for the areas in which the human resource function could provide a service to the front-line manager.

The eighth question consisted of the ten attributes listed in the Parasuraman et al. (1985) model. Each of these attributes was explained in a short statement to ensure understanding. Respondents were asked to rate each attribute on a scale of one to ten, where one was equal to 'totally unimportant', and ten equal to 'very important'.

The last question required respondents to list additional attributes characteristic of high quality service. The openended nature of the question gave the respondent the opportunity to identify attributes which were not mentioned in the model, but which they felt were significant to service quality.

The questionnaire was pretested by administering it to and discussing it with, the eight respondents who participated in the preliminary skill verification intervicws. During this pretest, the time required to complete the questionnaire was determined, flaws identified and, where necessary, questions rephrased.

\section{Method of analysis}

The data were compared on a question-by-question-basis. Medians and interquartile ranges were determined for responses to questions four to six, and the responses to question seven were summarized in a frequency distribution table. Data obtained in response to question eight allowed for comparison between the four respondent groups. Whereas quantitative judgement methods of data collection allow for more substantive statistical analyses, they demonstrate significant problems which led to the decision to use a variability method of data collection, i.e. respondents were asked to rate the attributes on a scale of one (least important) to ten (most important). The most significant shortcoming of the resultant ordinal scaled data was that the ranking of the data points were not necessarily uniform.

Medians and inter-quartile ranges were estimated from the ordinal data obtained in response to question eight to give some measure of the consensus with regard to the ratings by each respondent group. Data obtained were then analyzed using Thurstone's Case V Scale Model (Green \& Tull, 1978). This model permits the construction of a unidimensional interval scale using responses from variability data collection procedures, such as paired comparisons of the type, 'A is more important than B', thus making it an appropriate analysis technique for data obtained in response to this question.

Each individual respondent's rated auributes were grouped by the respondent group, using the above method, and a set of unidimensional interval scales derived for each of the four groups, namely, managing directors, human resource directors, functional directors and first-line managers. These were then factored in order to construct an aesthetically pleasing, standard interval scale, which permitted interpretation in answer to the research question.

\section{Results and discussion}

Forty completed questionnaires were received from the randomly selected ten companies, representing a one hundred percent response rate. There was a bias in the sample, as six of the ten companies could be described as being in the service industry.

\section{Sample demographics}

An examination of questions four, five and six was done on the total sample and not by the respondent group. Medians and inter-quartile ranges were determined for these responses. The results for the questions are presented in Table 1.

As the sample of each respondent group was very small, correlation statistics on demographic data could not be justified. However, two aspects relating to first-line managers were of particular interest. It was noted that on average the first-line managers had been in a supervisory position for a far shorter period than other respondents had held their respective positions. This could suggest that higher staff turnover was characteristic of the supervisory position. The high median age of the respondents representing first-line managers is in line with the survey data captured by Bittel \& Ramsey (1983) in their nation-wide survey of more than 
Table 1 Sample demographics

\begin{tabular}{llrlr}
\hline Question Respondents & N & \multicolumn{1}{c}{ Median class } & Median \\
\hline 4 & Sample & 40 & 1 to 5 years in position & 3.70 \\
4 & MD & 10 & 1 to 5 years in position & 4.10 \\
4 & HRD & 10 & 1 to 5 years in position & 3.50 \\
4 & FD & 10 & 1 to 5 years in position & 5.00 \\
4 & FLM & 10 & 1 to 5 years in position & 2.00 \\
5 & Sample & 40 & more than 5 years with company & 21.40 \\
5 & MD & 10 & more than 5 years with company & 26.50 \\
5 & HRD & 10 & more than 5 years with company & 12.80 \\
5 & FD & 10 & more than 5 years with company & 24.20 \\
5 & FLM & 10 & more than 5 years with company & 17.70 \\
6 & Sample & 39 & 34 to 49 years old & 43.80 \\
6 & MD & 10 & 34 to 49 years old & 43.30 \\
6 & HRD & 10 & 34 to 49 years old & 47.00 \\
6 & FD & 10 & 34 to 49 years old & 44.40 \\
6 & FLM & 9 & 34 to 49 years old & 41.00 \\
\hline
\end{tabular}

7000 supervisors. They reported that supervisors surveyed were not particularly young: $58 \%$ were between thirty and fifty years old, $22 \%$ were over fifty. Bittel \& Ramsey (1983) also reponted that supervisors were long service employees: two thirds of their respondents had worked for their employers for more than five years.

In this research, the median age of 41 also indicates that those employees who knew operations well, appeared to be promoted to supervisory positions late in their careers. This in itself could be a contributing factor to staff turnover at first-line management level. However, those first-line managers who participated in this research were also long service employees, having served in their respective companies for an average of almost 18 years.

Human resource skills and abilities of the first-line manager

The responses to question seven, in which respondents were asked which human resource skills and abilities were required by the first-line manager in his capacity as supervisor, are presented graphically in Figure 1. Skill and abili-

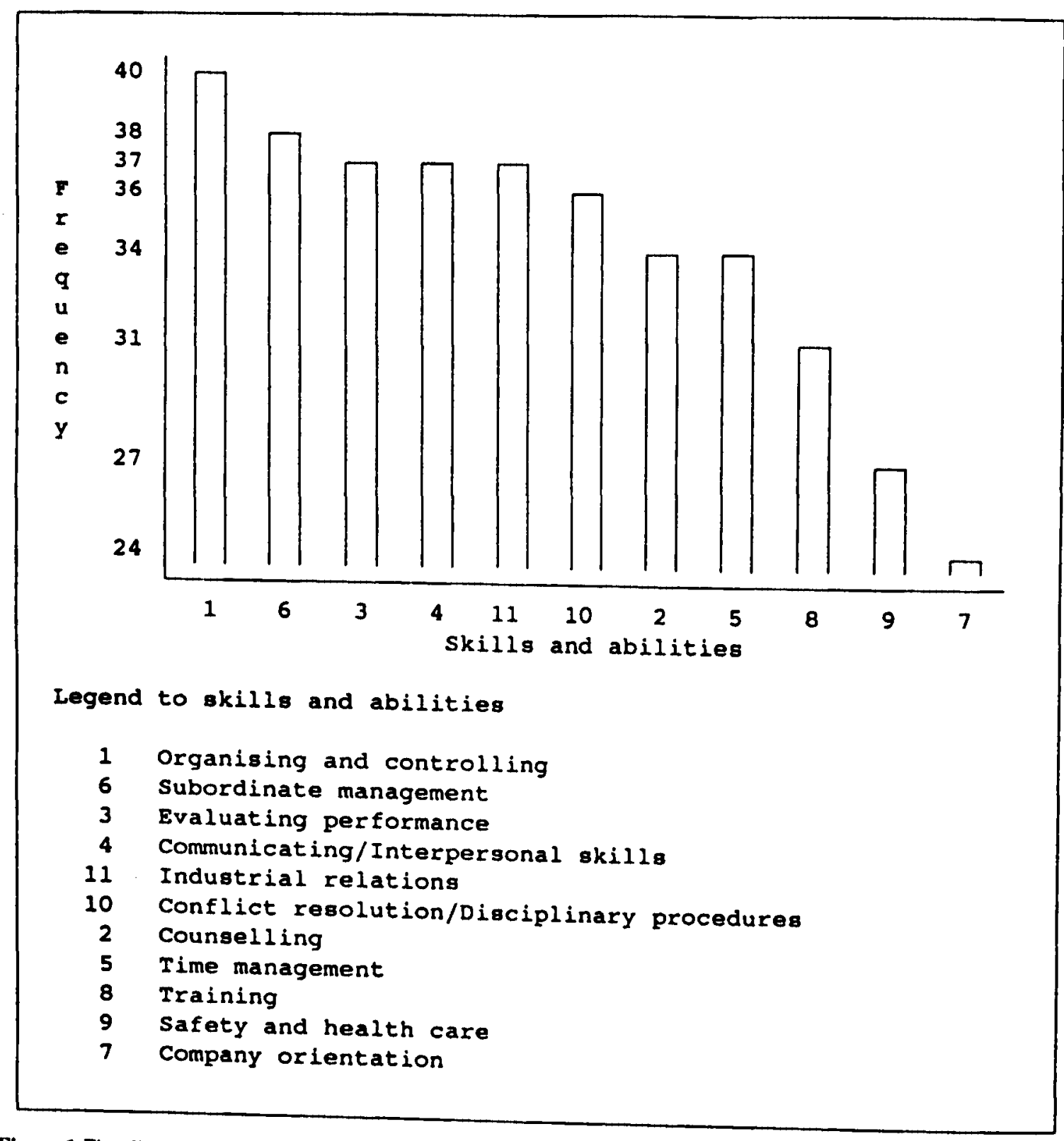

Figure 1 First-line manager's human resource skills and abilities 
ties are ranked, starting with the one most frequently selected.

Closer visual inspection revealed that there was a high level of consensus regarding the importance of the skills and abilities ranked in the first six positions, namely, organizing and controlling, subordinate management, evaluating performance, communicating/interpersonal skills, industrial relations, and conflict resolution/disciplinary procedures.

Of particular interest was the unanimous rating of 'organizing and controlling', an operational job-related skill. This supports the comment that first-line managers are promoted based on their ability to do the job. This also supports the observation made by Warrick \& Zawacki (1984) that supervisors who are usually more concerned with the daily scheduling of work, required specific supervisory skills. In addition, the low rating given to 'company orientation' possibly suggests that respondents did not identify with the vocabulary used. It could be speculated that had 'company/ job induction' been used, it would not have been rated as low, unless respondents saw this area of responsibility as being that of the human resource function.

Inspection of Figure 1 also raised the question of nonrespondents, which was therefore examined. A very low non-response rate was found among human resources directors. This could indicate their greater understanding of the demands of the first-line managers's job in terms of the human resource function they have as supervisors of employees. The study may therefore have been of more interest to this group of respondents. Managing directors had the highest non-response rate, followed closely by first-line managers. The explanation could lie in the fact that managing directors are most removed from the supervisory position. The front-line managers' perceptions could be an indication of their ignorance concerning the true nature of a supervisory role.
Rated service quality attributes

The major objective of the research was to obtain a rating of the service quality attributes of the Parasuraman, et al. (1985) service quality model as applied to the service rendered by the human resource function to the organization's first-line manager. The organizational focus of the study was thus internal. To achieve this, each respondent was asked to rate each of the ten service quality attributes on a scale from one to ten. Medians, inter-quartile ranges and the interval scale generated using Thurstone's Case $V$ Scale Model, were then analyzed.

\section{Median and inter-quartile range by attribute by re- spondent group}

The data in response to question eight represent the respondents' particular perceptions conceming the importance rating of each of the service quality attributes. Medians and inter-quartile ranges were estimated for each attribute to ascertain the measure of consensus of agreement within each group regarding the relative importance of attributes.

The findings for each of the ten attributes and for each of the respondent groups (managing directors, human resource directors, functional directors and first-line managers) are reported in Table 2 . The medians calculated for all attributes in each of the respondent groups agreed well with the rankings devised by the application of Thurstone's Case V Scale Model.

The inter-quartile ranges gave a measure of the consensus each respondent group demonstrated with regard to each specific attribute. The ranges calculated gave an indication of how much in agreement group members were about the importance of a specific attribute.

Consideration of individual attributes showed that the level of consensus noted for 'Accessibility', 'Communication', 'Responsiveness' and 'Security' was relatively

Table 2 Median and inter-quartile range for each attribute by respondent group

\begin{tabular}{|c|c|c|c|c|c|c|c|c|}
\hline \multirow[t]{3}{*}{ Attribute } & \multicolumn{8}{|c|}{ Respondent group } \\
\hline & \multicolumn{2}{|c|}{$\begin{array}{l}\text { Managing } \\
\text { directors }\end{array}$} & \multicolumn{2}{|c|}{$\begin{array}{l}\text { Human resources } \\
\text { directors }\end{array}$} & \multicolumn{2}{|c|}{$\begin{array}{l}\text { Functional } \\
\text { directors }\end{array}$} & \multicolumn{2}{|c|}{$\begin{array}{l}\text { First-line } \\
\text { managers }\end{array}$} \\
\hline & Median & $\begin{array}{l}\text { Inter- } \\
\text { quartile } \\
\text { range }\end{array}$ & Median & $\begin{array}{l}\text { Inter- } \\
\text { quartile } \\
\text { range }\end{array}$ & Median & $\begin{array}{l}\text { Inter- } \\
\text { quartile } \\
\text { range }\end{array}$ & Median & $\begin{array}{l}\text { Inter- } \\
\text { quartile } \\
\text { range }\end{array}$ \\
\hline Accessibility & 9.00 & 3.00 & 7.50 & 3.00 & 6.00 & 4.00 & 6.00 & 4.00 \\
\hline Cornmunication & 9.00 & 3.00 & 10.00 & 2.00 & 8.00 & 3.00 & 9.50 & 3.00 \\
\hline Competence & 10.00 & 2.00 & 10.00 & 3.00 & 9.00 & 200 & 9.00 & 1.00 \\
\hline Countesy & 7.00 & 4.00 & 7.00 & 4.00 & 5.50 & 7.00 & 5.50 & 5.00 \\
\hline Credibility & 10.00 & 1.00 & 9.00 & 2.00 & 9.00 & 0.00 & 8.50 & 4.00 \\
\hline Reliability & 9.50 & 1.00 & 8.00 & 4.00 & 8.00 & 1.00 & 7.00 & 2.00 \\
\hline Responsiveness & 8.50 & 3.00 & 8.00 & 4.00 & 7.50 & 3.00 & 6.00 & 4.00 \\
\hline Security & 7.50 & 4.00 & 7.00 & 4.00 & 5.50 & 5.00 & 2.00 & 5.00 \\
\hline Tangibles & 6.00 & 5.00 & 6.00 & 7.00 & 5.50 & 5.00 & 2.50 & 5.00 \\
\hline \multicolumn{9}{|l|}{ Understanding/ } \\
\hline $\begin{array}{l}\text { knowing the } \\
\text { customer }\end{array}$ & 9.50 & 2.00 & 9.00 & 3.00 & 8.00 & 3.00 & 6.00 & 4.00 \\
\hline
\end{tabular}


consistent, each attribute's inter-quartile ranges differed by up to three points. The least measure of consensus was noted for 'Credibility', its range stretching over four points.

There was generally a narrow region of disagreement about the level of importance for attributes rated as being most important by virtue of median scores of nine, nine and a half, and ten. This was defined by a low inter-quartile score of between zero and three. Generally the widest divergence of opinion was noted on the level of importance for those atuributes whose median scores ranged from two to six, their inter-quartile ranges from four to seven points.

Having considered to some extent the levels of consensus for each attribute, a discussion of levels of consensus within respective respondent groups follows. The focus of consensus remains the respective respondent groups' perceptions of the service provided by the human resource function to the first-line manager. Salient features, supported by scrutiny of both medians and inter-quartile ranges, are highlighted.

Managing directors appeared to agree about the relative importance of 'Credibility' and 'Reliability', and were most divergent in their view on 'Tangibles'. The first-line managers displayed similar levels of consensus in their rating of 'Competence', but were as divergent in their views on the importance of 'Credibility', whereas they were highly divergent in their perceptions about 'Courtesy', for which an inter-quartile range of seven was calculated. A range of seven was also estimated for 'Tangibles' as rated by human resource directors.

\section{Results of Thurstone's Case V Scale Model analysis by respondent group}

Ranked data responses from individual respondents were manipulated using Thurstone's Case V Scale Model to transform the raw ordinal data into a ranked interval scale. The raw data from the initial Thurstone Case V Scale Model analysis are shown in Table 3. As Thurstone's Case V Scale Model has an arbitrary zero point, it was determined to add the largest negative response, i.e. -1.64 , to all the raw data points. The largest negative response occurred in the human

Table 3 Raw data from the initial Thurston Case V Scale Model analysis

\begin{tabular}{|c|c|c|c|c|}
\hline \multirow[t]{2}{*}{ Attribute } & \multicolumn{4}{|c|}{ Respondent group } \\
\hline & $\begin{array}{l}\text { Managing } \\
\text { directors }\end{array}$ & $\begin{array}{l}\text { Human resour- } \\
\text { ces directors }\end{array}$ & $\begin{array}{l}\text { Functional } \\
\text { directors }\end{array}$ & $\begin{array}{l}\text { First-line } \\
\text { managers }\end{array}$ \\
\hline Accessibility & -0.78 & -0.14 & -0.50 & -0.62 \\
\hline Communication & -0.15 & 0.81 & -0.13 & 0.44 \\
\hline Competence & 0.69 & 0.30 & 0.38 & 1.02 \\
\hline Courtesy & -1.01 & -1.12 & -0.96 & -0.10 \\
\hline Credibility & 0.80 & 0.95 & 1.17 & 0.58 \\
\hline Reliability & 0.58 & 0.23 & 0.30 & 0.41 \\
\hline Responsiveness & -0.15 & 0.08 & 0.31 & -0.12 \\
\hline Security & -0.33 & -0.43 & -0.64 & -0.72 \\
\hline Tangibles & -1.35 & -1.64 & -0.32 & -0.83 \\
\hline \multicolumn{5}{|l|}{ Understanding/ } \\
\hline \multicolumn{5}{|l|}{ knowing the } \\
\hline customer & 1.57 & 0.96 & 0.38 & -0.11 \\
\hline
\end{tabular}

resources directors' assessment of the importance of 'Tangibles'. Thus this particular response became the arbitrary zero point.

Factoring the largest intermediate datum response from the above-mentioned manipulation to become ten units, enables the researcher to represent the data elegantly. This manipulation was permissable as Thurstone's Case V Scale Model measures relative differences in the ranking of atributes as opposed to absolute differences. The factor selected was for the intermediate datum point relating to the managing director's rating of 'Understanding/knowing the customer', i.e. 0.32 . The final data set created as a result of both of the above-mentioned treatments is shown in ordered rank in Table 4. Whilst an overview of the ordered rankings is given in this table, it fails to give any indication of the degree of importance of the attributes relative to one another. Thus the data from Table 4 are presented diagrammatically in Figure 2. This diagram simplifies the interpretation of the different levels of importance attached to the rankings of service quality attributes by the different respondent groups.

\section{Interpretation of the results of Thurstone's Case V Scale Model analysis}

The first feature that immediately became apparent when comparing the rankings of the individual respondent groups was that, overall, managing directors showed a more dispersed, more consistently held set of responses than any of the other respondent groups. This breadth of concern by managing directors indicated their certainty about which items were perceived by the customers (i.e. the first-line managers) of the human resource function as being very important.

Conversely, overall, the group of first-line managers showed both the tightest and weakest range of responses. This suggests that they were more uncertain about which attributes were important in their being more focussed in their perceptions. It could be said that there appears to be a trend of declining certainty by lower job level in the hierarchy:

Table 4 Final data from the Thurston Case $V$ Scale Model analysis

\begin{tabular}{lcccc}
\hline No autribute & Respondent group & & \\
\hline & $\begin{array}{c}\text { Managing } \\
\text { directors }\end{array}$ & $\begin{array}{c}\text { Human resour- } \\
\text { ces directors }\end{array}$ & $\begin{array}{c}\text { Functional } \\
\text { directors }\end{array}$ & $\begin{array}{c}\text { First-line } \\
\text { managers }\end{array}$ \\
\hline 1 Accessibility & 2.67 & 4.67 & 3.54 & 3.17 \\
2 Communication & 4.64 & 7.64 & 4.70 & 6.48 \\
3 Competence & 7.25 & 6.03 & 6.30 & 8.28 \\
4 Courtesy & 1.95 & 1.62 & 2.12 & 4.80 \\
5 Credibility & 7.61 & 8.05 & 8.76 & 6.90 \\
6 Reliability & 6.92 & 5.82 & 6.03 & 6.39 \\
7 Responsiveness & 4.63 & 5.34 & 6.07 & 4.72 \\
8 Security & 4.07 & 3.76 & 3.10 & 2.85 \\
9 Tangibles & 0.90 & 0.00 & 4.12 & 2.53 \\
10 Understanding/ & & & & \\
$\quad$ knowing & & 8.09 & 6.29 & 4.75 \\
$\quad$ the customer & 10.00 & & & \\
\hline
\end{tabular}




\begin{tabular}{|c|c|c|c|c|c|c|c|}
\hline & $\begin{array}{l}\text { Managing } \\
\text { directors }\end{array}$ & & $\begin{array}{l}\text { Human resour- } \\
\text { ces directors }\end{array}$ & & $\begin{array}{l}\text { Functional } \\
\text { directors }\end{array}$ & & $\begin{array}{l}\text { First-line } \\
\text { managers }\end{array}$ \\
\hline 10.00 & Customer $^{1}$ & 10.00 & & 10.00 & & 10.00 & \\
\hline 9.50 & & 9.50 & & 9.50 & & 9.50 & \\
\hline 9.00 & & 9.00 & & 9.00 & Credibility & 9.00 & \\
\hline 8.50 & & 8.50 & Customer & 8.50 & & 8.50 & Competence \\
\hline 8.00 & & 8.00 & Credibility & 8.00 & & 8.00 & \\
\hline 7.50 & $\begin{array}{l}\text { Credibility } \\
\text { Competence }\end{array}$ & 7.50 & Communication & 7.50 & & 7.50 & \\
\hline 7.00 & Reliability & 7.00 & & 7.00 & & 7.00 & Credibility \\
\hline 6.50 & & 6.50 & & 6.50 & $\begin{array}{l}\text { Competence } \\
\text { Customer }\end{array}$ & 6.50 & Communication \\
\hline 6.00 & & 6.00 & $\begin{array}{l}\text { Competence } \\
\text { Reliability }\end{array}$ & 6.00 & $\begin{array}{l}\text { Responsiveness } \\
\text { Reliability }\end{array}$ & 6.00 & Reliability \\
\hline 5.50 & & 5.50 & & 5.50 & & 5.50 & \\
\hline 5.00 & Communication & 5.00 & Responsiveness & 5.00 & Communication & 5.00 & $\begin{array}{l}\text { Courtesy } \\
\text { Customer }\end{array}$ \\
\hline 4.50 & Responsiveness & 4.50 & Accessibility & 4.50 & & 4.50 & Responsiveness \\
\hline 4.00 & Security & 4.00 & Security & 4.00 & Tangibles & 4.00 & \\
\hline 3.50 & & 3.50 & & 3.50 & Accessibility & 3.50 & \\
\hline 3.00 & & 3.00 & & 3.00 & Security & 3.00 & $\begin{array}{l}\text { Accessibility } \\
\text { Security }\end{array}$ \\
\hline 2.50 & Accessibility & 2.50 & & 2.50 & & $2.50^{\circ}$ & Tangibles \\
\hline 2.00 & Courtesy & 2.00 & & 2.00 & Courtesy & 2.00 & \\
\hline 1.50 & & 1.50 & Courtesy & 1.50 & & 1.50 & \\
\hline 1.00 & Tangibles & 1.00 & & 1.00 & & 1.00 & \\
\hline 0.50 & & 0.50 & & 0.50 & & 0.50 & \\
\hline 0.00 & & 0.00 & Tangibles & 0.00 & & 0.00 & \\
\hline \multicolumn{8}{|c|}{ Overall ranges } \\
\hline 9.10 & & 8.09 & & 6.64 & & 5.75 & \\
\hline
\end{tabular}

Figure 2 Thurston's Case V Unidimensional Interval Scale for each respondent group

managing director - director - manager. This could indicate that, in terms of a service provided by the human resource function, needs vary by level, or that the support role of the human resource function is poorly understood and needs to be better communicated.

All respondent groups ranked 'Reliability' in either the fourth or fifth position over a scale range of 2.22 . This indicated a relatively high level of consensus amongst all four respondent groups as to its scrutiny, and it cannot be regarded as a contentious issue. Similarly, respondents also did not regard 'Responsiveness' as an issue for the customers.

Thirdly, the groups of managing directors, human resource directors and functional directors rated 'Tangibles', 'Security' 'Accessibility' and 'Courtesy' of lesser importance to the first-line manager as customer of the human resource function. These atuributes of perceived lesser importance had a scale range of 4.67. Although first-line managers also rated these attributes of lesser importance, over a scale range of 4.80 , two additional attributes, namely 'Understanding/knowing the customer' and 'Responsiveness', were also perceived by them as being of lesser importance, and within the range. This suggests that first-line managers perceived the human resource function as being close to them as a customer group, responding to their needs. It could also indicate an insensitivity to the concept of internal marketing, or point to a reservation within this group to be critical of colleagues. A possible explanation for their rating of 'Courtesy' could be that first-line managers did not perceive interactions with the human resource function always to be courteous, thus explaining the relative importance they placed on this aturibute, ranking it in the fourth position.

The different ranking given to 'Tangibles' by functional directors indicated that they believe that first-line managers used it to judge the service provided by the human resource function. This clcarly indicates that the human resource function should get this aspect of their service right in their dealings with supervisors. This opinion was, however, not shared by any of the other respondent groups.

An interesting result was produced with regard to the ranking of 'Understanding/knowing the customer' in terms of the service provided to first-line managers by the human 
resource function. It was ranked as being most imponant by both managing directors and human resource directors, at 10.00 and 8.09 respectively. However, 'Understanding/ knowing the customer' was ranked in the third position by functional directors and given a sixth position by first-line managers.

It could be surmised that the high ranking given it by managing directors influences the perceptions of its relative importance by human resource directors. The latter appreciate that, indirectly, a service needs to be provided by managing directors in terms of a service rendered to their subordinates, the front-line managers in the organization.

The second significant feature pertained to the atributes of 'Competence' and 'Credibility', which were consistently rated by each respondent group among its four attributes. However, this consistency was only noted over a fairly wide scale range of 3.97 .

'Competence' was highly valued by first-line managers whose desire it appears to be effective on the job by possessing appropriate skills and abilities. This supports the earlier findings in response to question seven, which related to the high frequency selection of operational job-related human skills and abilities. It was also hypothesized that job competence was an important criterion for promotion to the position of first-line manager. The first-line manager is thus looking to a competent team in the human resources function to assist him in his preparation for the additional responsibility of managing workers. Of note is that the relative importance placed on 'Competence' was also shared by managing directors.

Functional directors emphasized 'Credibility' in their ratings, indicating that human resources directors must market their service to the first-line managers. It is to human resource directors that first-line managers look for possession of required supervisory skills. This puts pressure on the human resources directors and explains their high rating of 'Credibility' relative to their service to first-line managers.

The ratings of 'Communication' reinforce the findings to question seven. Communication is a skill or ability that is being pushed down the line. This is evident from the relatively high ratings given to it by first-line managers and human resource directors, in contrast to the relatively low ratings given to it by managing directors and functional directors.

The tight cluster of priority ratings given to attributes by human resource directors indicates that they understand the needs of their first-line customers: 'Understanding/knowing the customer', 'Credibility' and 'Competence' being well represented in their priority cluster. It could be hypothesized that if one were to measure the size of Gap 1 in this research, it would not be extremely large. However, this supposition may be premature, since this was not the purpose of the research.

\section{Additional service qualities}

Eighteen responses to the concluding open-ended question were received. These are summarized in Table 5. Most of these additional attributes listed by respondents correspond with either skills and abilities listed in question seven, or
Table 5 Additional service quality attributes

\begin{tabular}{lc}
\hline Statement & Question \\
\hline Ability to relate to a wide spectrum of managers/personnel & $(7 \mathrm{~d})$ \\
Total dedication to the company & $(7 \mathrm{~g})$ \\
Appreciation of legal implications of matters discussed & $(7 \mathrm{k})$ \\
Relate to labour management problems & $(7 \mathrm{k})$ \\
Understand and know the business & $(8 \mathrm{c})$ \\
Knowledge and expertise & $(8 \mathrm{c})$ \\
Professionalism & $(8 \mathrm{c})$ \\
Autention to detail & $(8 \mathrm{f})$ \\
Fast action to resolve problems & $(8 \mathrm{~g})$ \\
Ability to make on the spot decisions & $(8 g)$ \\
Confidentiality & $(8 \mathrm{~h})$ \\
Vision & \\
Flexibility & \\
Common sense and a high energy level & \\
Assertiveness in providing the service & \\
Effectiveness & \\
Sound business/commercial acumen & \\
Maturity &
\end{tabular}

service quality attributes listed in question eight. Similarities are indicated in parenthesis. These additional comments were randomly spread among respondents and no clear trend of concern by respondent group was identified.

In addition, the nature of some of the responses indicated that respondents may not have fully understood the question. This could have been a result of a poorly constructed question, in spite of assurances that the question was phrased unambiguously during the pilot test of the questionnaire.

\section{Summary and conclusions}

In conclusion, it would not be inappropriate to consider the possibility that Parasuraman et al. (1985) have oversimplified the concept of service quality. It could be postulated that service providers who actively go about providing a service to consumers, create expectations in the consumer group. The way the service is valued is influenced by the existence of perceptual gaps. In the application of the model to a service provider consumer group within the same organization, it would appear that the gap is impacted by the consumer's level in the organization.

Differences in perceptions of the service provided by the human resource function could also be influenced by the frequency, nature and level of contact with the human resource function. This appears to be the case if one reexamines Figure 1, comparing the gap between the human resources and managing directors with the gap that exists between human resources directors and other line managers. It would appear that the greater the contact, as in the case of human resources and managing directors, the greater the influence. This manifests itself in the hierarchically different ratings noted in this research. However, it may be that the human resource function deliberately does not set itself up as a service provider, so as not to create consumer expectations. 
Numerous authors, such as Lewis (1974); Leonard \& Sasser (1980); Warrick \& Zawacki (1984), have stressed that people skills are something that all supervisors need to acquire. In addition, others have pointed out that the human resources function is owned by line management (Cascio, 1986). These arguments point strongly towards the marketing role of the human resources function (Cascio, 1986) in that it should communicate clearly to management what it could offer and what could be expected from it. This would control the size of Gap 1 which this study found to exist between human resources directors and their consumers, namely, line management.

Finally, the research indicated some validity for the model of Parasuraman et al. (1985), when applied to the provision of a service within an organization. However, the additional attributes generated indicate that the attributes of their model may well be modified under different circumstances. This needs to be further researched; this research could be repeated on a larger scale to confirm the findings and also extended to other services provided within an organization.

\section{References}

Barrington, H. 1978. 'Developing personnel training for the management trainee', Personnel Management, Vol. 10, No. 10: $38-41$.

Beckwith, N.E. \& Fitzgerald, T. 1981. 'Marketing of services meeting of different needs'. In: Donnelly, J.H. \& George, W.R. (eds.). Marketing of services. Chicago: American Marketing Association, pp. 239-241.

Bennis, W.G. \& Nanus, B. 1985. Leaders: The stralegies for taking charge. New York: Harper and Row.

Berry, L.L. 1980. 'Services marketing is different'. In: Lovelock, C.H. (ed.). Services marketing: text, cases and readings. Englewood Cliff, New Jersey: Prentice-Hall, pp.29-37.

Boome, B.H. \& Bitner, M.J. 1981. 'Marketing strategies and organisation structures for service firms'. In: Donnelly, J.H. \& George, W.R. (eds.). Marketing of services. Chicago: American Marketing Association, pp.47-51.

Cascio, W.F. 1986. Managing human resources: Productivity, quality of work life, profits. Singapore: McGraw-Hill, 625p.

Chambers Twentieth Century Dictionary. 1974. Macdonald, A.M. (Ed.). New Edition. Edinburgh: T \& A Constable Lid. 1639p.

Churchill, G.A. \& Suprenant, C. 1982. 'An investigation into the determinants of customer satisfaction', Journal of Marketing Research, Vol. 19. November, pp.491-504.

Crosby, P.B. 1979. Quality is free: the art of making quality certain. New York: New American Library, 270p.

Day, R.L. 1977. 'Extending the concept of consumer satisfaction'. In Perrault W.D. (ed.). Advances in consumer research, Vol. 4. Atlanta: Association for Consumer Research.

Enis, B.M. \& Roering, K.J. 1981. 'Services marketing: different products similar strategy. In: Donnelly, J.H. \& George, W.R. (eds.). Marketing of services. Chicago: American Marketing Association, pp. $1-4$.

Fisk, R.P. 1981. 'Toward a consumption/evaluation process model for services'. In: Donnelly, J.H. \& George, W.R. (eds.). Marketing of services. Chicago: American Marketing Association, pp.191-195.

Garvin, D.A. 1983. 'Quality on the line', Harvard Business Review, Vol. 61, No. 5 (September-October): 65-73.

Green, P. \& Tuil, S. 1978. Research for marketing decisions. 4th edition. Englewood Cliffs, New Jersey: Prentice-Hall, 673p.

Gronroos, C. 1984. 'A service quality model and its marketing implications', European Journal of Marketing, Vol. 18, No. 4: 36-44.

Hawkins, D.I., Coney, K.A. \& Best, RJ. 1980. Consumer behaviour: implications for managerial stralegy. Dallas: Business Publications.

Jacobs, L.E. 1988. Perceptions of quality in the private physio. therapy practice. Unpublished MBA research report. Johannesburg: University of the Witwatersrand.

Kirkpatrick, D.L. 1990. 'Effective supervisory training and development. Part 2: In-house approaches and techniques', Personnel (AMA), Vol. 62, No. 1: 52-56.

Kotler, P. 1988. Marketing management: analysis, planning, implementation and control. 6th edition. Englewood Cliffs, New Jersey Prentice-Hall, 777p.

Lehtinen, U. \& Lehtinen, J.R. 1982. Service quality: a sludy of quality dimensions. Unpublished working paper. Helsinki: Service Management Institute.

Leonard, F.S. \& Sasser, W.E. 1982. 'The incline of quality', Harvard Business Review, Vol. 60, No. 5 (SeptemberOctober): 163-171.

Lewis, B.D. 1974. 'The supervisor in 1975', Personnel Journal, Vol. 52, No. 9 (September): 815-818.

Lewis, R.C. \& Booms, B.H. 1983. 'The marketing aspects of service quality'. In: Berry, L.L., Shostack, G.L. \& Upah, G.D. (eds.). Emerging perspectives on services marketing. Chicago: American Marketing Association, pp.99-104.

Lovelock, C.H. 1984a. 'Managing the service marketing system'. In: Lovelock, C.H. (ed.). Services marketing: tex, cases and readings. Englewood Cliffs, New Jersey: Prentice-Hall, pp.339-347.

Ortinau, D.J. 1979. 'A conceptual model for consumers; post purchase satisfaction/dissatisfaction decision process'. In : Day, R.L. \& Hunt, H.K. (eds.). New dimensions of consumer satisfaction and complaining behaviour. Bloomington: Indiana University.

Parasuraman, A., Zeithaml, A.V. \& Benry, L.L. 1985. 'A conceptual model of service quality and its implications for future research', Journal of Marketing. Vol. 49, No. 4: 41-50.

Peters, T. 1987. Thriving on chaos: Handbook for a management revolution. New York: A. Korfman Inc.

Prokopenko, J. \& Bittel, L.R. 1981. 'A modular course-format for supervisory development', Training and Development Journal, Vol. 35, No. 2: 14-20.

Rabin, J.H. 1983. 'Accent is on quality in consumer services this decade', Marketing News, Vol. 17, 4 March: 12.

Rathmell, J.M. 1966. 'What is meant by services?' Journal of Marketing, Vol. 30, No. 4: 32-36.

Sasser, W.E., Olsen, R.P. \& Wyckoff, D.D. 1978. Management of service operations: tex and cases. Boston: Allyn \& Bacon, $734 \mathrm{p}$.

Shostack, G.L. 1977. 'Breaking free from product marketing', Journal of Marketing, Vol. 41, No. 2: 73-80.

Smith, R.A. \& Housten, M.J. 1983. 'Script-based evaluations of satisfaction with services. In: Berry, L.L., Shostack, G.L. \& Upah, G.D. (eds.). Emerging perspectives on services marketing. Chicago: American Marketing Association. pp.59-62.

Takeuchi, H. \& Quelch, J.A. 1983. 'Quality is more than making a good product', Harvard Business Review, Vol. 61, No. 4 (July-August): 139-145.

Warrick, D.D. \& Zawachi, R.A. 1984. Supervisory managemen: understanding behaviour and managing for results. New York: Harper and Row, 410p.

Zeithaml, A.V. 1981. 'How consumer evaluation processes differ between goods and services'. In: Donnelly. J.H. \& George, W.R. (eds.). Marketing of services. Chicago: American Marketing Association, pp.186-190. 